\title{
26.3. STABLE ISOTOPIC INVESTIGATION OF MESSINIAN SULFATE SAMPLES FROM DSDP LEG 42A, EASTERN MEDITERRANEAN SEA
}

\author{
T. E. Ricchiuto, ${ }^{1}$ Laboratorio Geologia Nucleare Universita' di Pisa, Italy \\ and \\ J. A. McKenzie, Swiss Federal Institute of Technology, Zurich, Switzerland
}

\begin{abstract}
The oxygen-18 and sulfur-34 ratios were measured on a series of samples selected at frequent intervals from sulfate sequences at three DSDP sites in the eastern Mediterranean. The results reveal the existence of three evaporite basins during the Messinian Salinity Crisis, each evolving in a different manner.
\end{abstract}

\section{INTRODUCTION}

The existence of deep desicated, inland basins in the upper Miocene Mediterranean was postulated to explain the vast evaporite deposits discovered during DSDP Leg 13 (Ryan, Hsü, et al., 1973). The purpose of this work was to study the evolution of these deposits using the techniques of stable isotope geochemistry.

During Leg $42 \mathrm{~A}$ drilling, extensive evaporite sequences were recovered at three sites in the eastern Mediterranean; Sites 374, 376, and Hole 378A. Samples were selected and analyzed at frequent intervals in the sulfate containing cores from these sites. This led to a comparative study of the evolution of three evaporite basins: the Ionian Basin, the Antalya Basin, and the Aegean Basin.

\section{RESULTS AND DISCUSSION}

Well-established procedures were used to measure the stable isotopic composition of the Leg 42A sulfates (Longinelli and Craig, 1967; Longinelli, 1968; Cortecci et al., 1975; Rafter, 1957). The isotopic data are reported in terminology with respect to the international standards: Standard Mean Ocean Water (SMOW) for oxygen-18 (Craig, 1961) and meteoric sulfur (Canyon Diablo Troilite, C.D.) for sulfur-34. The standard deviation of the isotopic analyses $(1 \sigma)$ is \pm 0.1 per mil $(\sigma)$ in the case of $\delta \mathrm{O}^{18}$ and \pm 0.15 per mil $(\mathrm{l} \sigma)$ in the case of $\delta \mathrm{S}^{34}$. The isotopic results of this study are reported in Tables 1,2 , and 3 for the respective evaporite basins. These data are graphically illustrated with respect to depth beneath the sea floor in Figures 1, 2, and 3. The isotopic results are discussed below separately for the individual basins.

\section{Site 374 - Ionian Basin}

The $\delta \mathrm{O}^{18}$ ratio of the sulfate shows a continuous, progressive trend towards more positive values from Core 22 to Core 16 . This marked evolution of the $\delta \mathrm{O}^{18}$

\footnotetext{
'Present address: AGIP-AMI, Servizio SGEL. I-20097 S. Donato Milanese, Milano, Italy
}

is not paralleled by a change in $\delta \mathbf{S}^{34}$. In spite of a wide range in the sulfur-34 composition of \pm 1 per mil, the average value remains at +22 per mil throughout the sequence. This indicates that the $\delta \mathrm{O}^{18}$ variation is not the result of bacteriological reduction. Bacterial reduction of sulfate ions produces an isotopic enrichment in the sulfur of the residual sulfate fraction which is four times greater than the corresponding enrichment in the oxygen (Mizutani and Rafter, 1969).

The dissolved sulfate in the present oceans is not in equilibrium. Its isotopic composition is in a steady-state condition probably maintained by biochemical redox activity (Lloyd, 1967). Although this hypothesis has

TABLE 1

Site 374 Results

\begin{tabular}{|c|c|c|c|}
\hline $\begin{array}{c}\text { Sample } \\
\text { (Interval in } \mathrm{cm} \text { ) }\end{array}$ & Mineral & $\delta 0^{18}$ vs SMOW & $\delta \mathrm{S}^{34}$ vs C.D. \\
\hline $16-1,68-69$ & Gypsum & +19.4 & +21.1 \\
\hline $16-1,114-117.5$ & Gypsum & +19.8 & +22.6 \\
\hline $16-1,126-127$ & Gypsum & +18.6 & +22.5 \\
\hline $17-1,35-40$ & Gypsum & +18.5 & +22.4 \\
\hline $17-1,90-92$ & Gypsum & +17.5 & +22.4 \\
\hline $17-1,112-115$ & Gypsum & +17.8 & +22.6 \\
\hline $17-1,116-118$ & Gypsum & +17.9 & +22.4 \\
\hline $17-1,128-132$ & Gypsum & +16.5 & +21.2 \\
\hline $18-1,126-127$ & Gypsum & +16.9 & +22.4 \\
\hline $18-1,131-133$ & Gypsum & +16.8 & +21.2 \\
\hline $18-1,138-140$ & Gypsum & +17.4 & +22.4 \\
\hline $19-1,6-8$ & Gypsum & +17.5 & +22.4 \\
\hline $19-1,55-56$ & Gypsum & +17.1 & +22.7 \\
\hline $19-1,92-94$ & Gypsum & +16.4 & +21.9 \\
\hline $19-1,116-119$ & Gypsum & +17.3 & +22.2 \\
\hline $20-1,123-126$ & Gypsum & +16.9 & +21.7 \\
\hline $21-1,103-105$ & Anhydrite & +16.4 & +21.5 \\
\hline $21-1,112-114$ & Gypsum & +15.8 & +22.4 \\
\hline $21-1,121-123$ & Anhydrite & +16.0 & +21.3 \\
\hline $21-1,130-132$ & Anhydrite & +16.1 & +20.8 \\
\hline $21-1,140-142$ & Anhydrite & +16.2 & +21.9 \\
\hline $21-1,148-150$ & Anhydrite & +15.9 & +21.8 \\
\hline $22-1,0-2$ & Anhydrite & +15.0 & +22.4 \\
\hline $22-1,10-12$ & Anhydrite & +15.3 & +22.4 \\
\hline $22-1,16-18$ & Anhydrite & +15.1 & +22.0 \\
\hline $22-1,29-31$ & Anhydrite & +14.9 & +22.4 \\
\hline $22-1,42-44$ & Anhydrite & +14.7 & +21.9 \\
\hline $22-1,50-52$ & Anhydrite & +15.2 & +22.3 \\
\hline $22-1,59-61$ & Anhydrite & +15.1 & +22.4 \\
\hline $22-1,70-72$ & Anhydrite & +14.6 & +21.4 \\
\hline
\end{tabular}


TABLE 2

Site 376 Results

\begin{tabular}{lccc}
\hline $\begin{array}{c}\text { Sample } \\
\text { (Interval in cm) }\end{array}$ & Mineral & $\delta \mathrm{O}^{18}$ vs SMOW & $\delta \mathrm{S}^{34}$ vs C.D. \\
\hline $17-1,80-81$ & Gypsum & +17.5 & +21.6 \\
$17-1,116-117$ & Gypsum & +18.8 & +22.1 \\
$18-1,63-65$ & Gypsum & +18.7 & +22.1 \\
$18-1,72-73$ & Gypsum & +18.6 & +22.4 \\
$18-1,105-106$ & Gypsum & +18.1 & +23.3 \\
$18-1,141-142$ & Gypsum & +20.0 & +24.8 \\
$18-1,142-143$ & Gypsum & +18.5 & +23.7 \\
$19-1,120-124$ & Gypsum & +18.8 & +22.5 \\
$19-1,126-127$ & Gypsum & +18.9 & +22.8 \\
$20-1,62-63$ & Gypsum & +18.1 & +25.7 \\
$20-1,89-90$ & Gypsum & +18.8 & +27.2 \\
$20-1,135-136$ & Gypsum & +14.5 & +23.3 \\
$20-1,139-140$ & Gypsum & +14.5 & +24.1 \\
$22-1,92-94$ & Anhydrite & +14.2 & +23.0 \\
$22-1,130-132$ & Anhydrite & +13.8 & +22.5 \\
\hline
\end{tabular}

TABLE 3

Site 378A Results

\begin{tabular}{llcc}
\hline $\begin{array}{c}\text { Sample } \\
\text { (Interval in cm) }\end{array}$ & Mineral & $\delta \mathrm{O}^{18}$ vs SMOW & $\delta \mathrm{S}^{34}$ vs C.D. \\
\hline $4-1,29-31$ & Gypsum & +14.5 & +20.8 \\
$4-1,50-52$ & Gypsum & +14.4 & +21.8 \\
$4-1,69-71$ & Gypsum & +15.2 & +22.1 \\
$4-1,93-95$ & Gypsum & +14.4 & +21.9 \\
$4-1,101-103$ & Gypsum & +14.5 & +22.7 \\
$4-1,120-122$ & Gypsum & +14.3 & +21.3 \\
$4-1,140-142$ & Gypsum & +14.8 & +22.5 \\
$5-1,50-52$ & Gypsum & +14.6 & +22.2 \\
$5-1,68-70$ & Gypsum & +14.6 & +23.1 \\
$5-1,91-93$ & Gypsum & +15.1 & +21.7 \\
$5-1,111-113$ & Gypsum & +14.9 & +23.1 \\
$5-1,125-127$ & Gypsum & +15.1 & +22.6 \\
$5-1,144-146$ & Gypsum & +14.7 & +23.5 \\
$6-1,60-62$ & Gypsum & +15.0 & +21.8 \\
$6-1,82-84$ & Gypsum & +15.1 & +23.7 \\
$6-1,105-106$ & Gypsum & +15.3 & +20.9 \\
$6-1,120-122$ & Gypsum & +15.0 & +23.7 \\
$6-1,143-145$ & Gypsum & +14.8 & +22.0 \\
\hline
\end{tabular}

not been proven, sulfate reducing and sulfur oxidizing bacteria are commonly found in both marine and fresh water environments.

With high rates of evaporation from a closed basin, the salt content is greatly increased. In extreme environmental conditions, as in brine solutions, bacterial activity can be drastically reduced or completely poisoned (Wallhauser and Puchelt, 1965). The depletion of bacterial activity would result in the initiation of the evolution of the oxygen isotopic composition of the sulfate toward the equilibrium value, which is considerably more positive than the isotopic results obtained. From Lloyd's (1967) data, the sulfate-water fractionation factor at $25^{\circ} \mathrm{C}$ is assumed to be equal to 1.0315 . In the case of the Messinian Ionian Basin, the gradual enrichment in oxygen- 18 of the dissolved sulfate is seen recorded with time in the progressive increase in $\mathrm{O}^{18}$ of the sulfate precipitated. Therefore, the maximum analyzed $\delta \mathrm{O}^{18}$ value of +19.8 per mil represents only an approachment of equilibrium. Perhaps, the continual input of new water and sulfate ions along
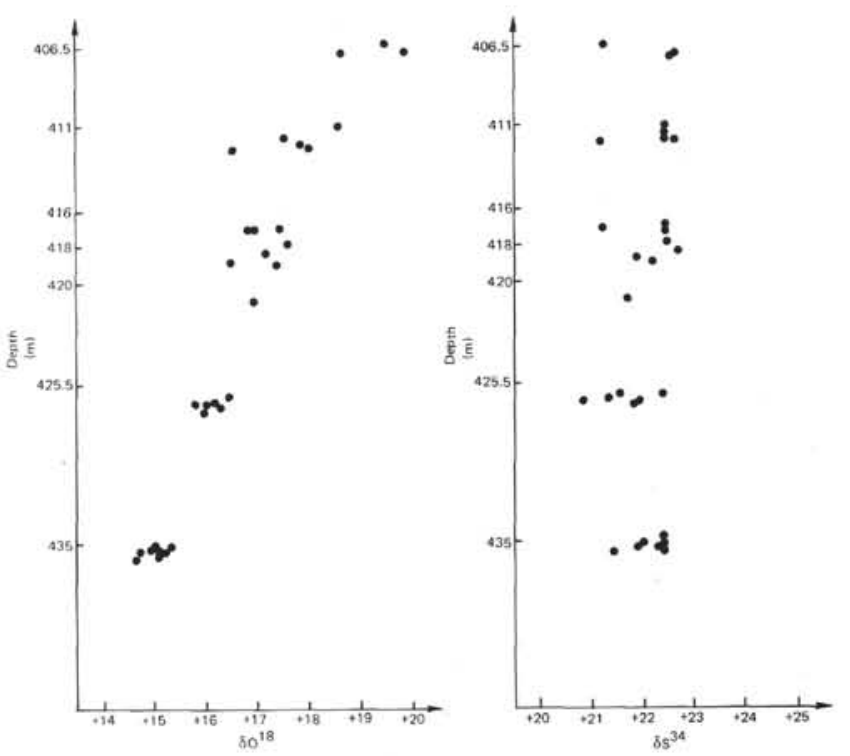

Figure 1. Plot of $\delta O^{18}$ and $\delta S^{34}$ in sulfates with respect to depth at Site 374, Ionian Basin.

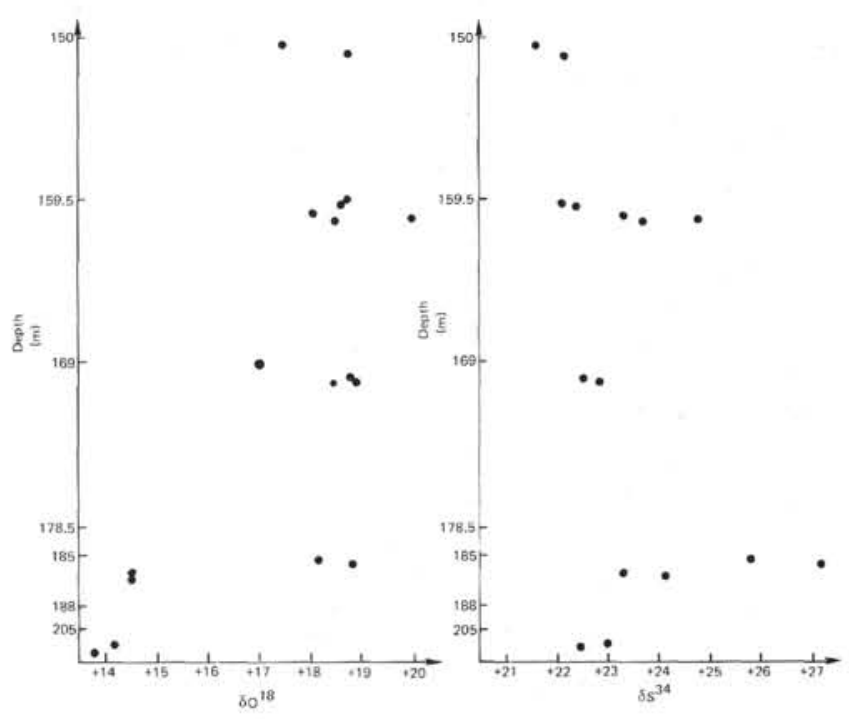

Figure 2. Plot of $\delta O^{18}$ and $\delta S^{34}$ in sulfates with respect to depth at Site 376, Antalya Basin.

with some bacterial activity at a very reduced rate prevented the attainment of complete isotopic equilibration.

The rate of the sulfate-water isotopic exchange process is extremely slow. Lloyd (1968) estimates that complete isotopic equilibration is attained in about $10^{4}$ to $10^{5}$ years. The average rate of Messinian sedimentation at Site 374 is estimated to have been on the order of $1 \mathrm{~m} /$ thousand years. The analyzed sulfates come from a sequence 38 meters thick, which formed in a period of about $40,000 \mathrm{yr}$. This length of time seems to agree reasonably with the amount of isotopic variation measured in the sulfate sequence. The fact that the $\delta \mathrm{O}^{18}$ value increases continuously without a break probably indicates that the basin was almost continuously flooded during the time of sulfate deposition. 

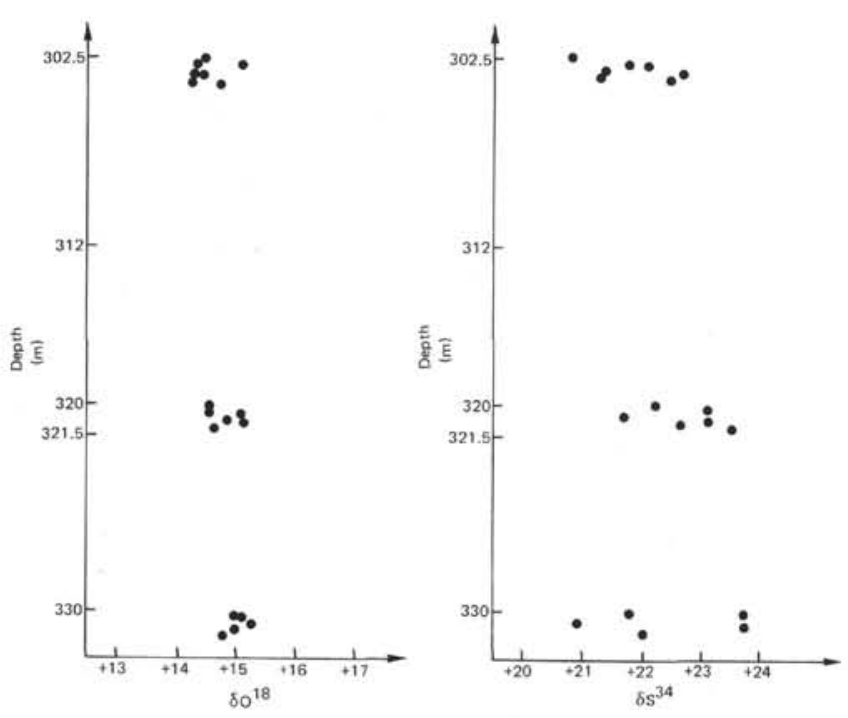

Figure 3. Plot of $\delta O^{18}$ and $\delta S^{34}$ in sulfates with respect to depth at site 378A, Aegean Basin.

However, sedimentary studies (Garrison et al., this volume) suggest periodic subaerial exposure at this site. The permanent water body must have existed somewhat deeper in the basin, where continuous isotopic evolution of the sulfate ions occurred. An influx of water into the basin is necessary to maintain a certain water level, but its influence was apparently not sufficient to refresh the water enough to revive high rates of bacterial activity.

\section{Site 376 - Antalya Basin - Florence Rise}

The stable isotopic data for the sulfates from Site 376 are quite different from those obtained at Site 374 .

Perhaps, this difference reflects the nonequivalent positioning of the drill sites within the two basins. Site 376 is located on the northern slope of the Florence Rise facing the Antalya Basin, while Site 374 is located near the deepest part of the Ionian Abyssal Plain. In the deeper parts of a basin, slight water level fluctuations are recorded sedimentologically as cycles of subaqueous-subaerial depositions (Garrison et al., this volume). In the higher parts of a basin, water level fluctuations can result in long periods of a complete desiccation, as reported below. Results from Cores 22 and 20 appear to indicate the onset of a similar isotopic equilibration trend, probably resulting from a diminished bacterial activity. Between $135-136 \mathrm{~cm}$ and $89-90 \mathrm{~cm}$ in Core 20, Section 1, there is a very sharp isotopic break. This very rapid change in $\delta \mathrm{O}^{18}$ and $\delta \mathrm{S}^{34}$ probably marks a sedimentary unconformity, a time of desiccation at Site 387. An influx of fresh waters raised the water level of the eastern Mediterranean LagoMare system. This water contained sulfate ions enriched in oxygen-18. The increase in $\delta \mathrm{S}^{34}$ at $89-90 \mathrm{~cm}$ is especially indicative of renewed bacteriological activity produced by a fresh input of water into the basin.

In Core 19, a reduction in bacteriological activity is again recorded as the $\delta \mathrm{S}^{34}$ ratio drops back to a value of approximately +22 per mil. The $\delta \mathrm{O}^{18}$ ratio remains enriched and practically constant at an average value of +18.6 per mil until the end of the gypsum deposition. There is no evidence for further sulfate-water isotopic equilibration at Site 376, although continued isotopic evolution was probably occurring deeper in the basin during the time of desiccation. The constancy of $\delta \mathrm{O}^{18}$ indicates a secondary source of sulfate ions other than the original source with a $\delta \mathrm{O}^{18}$ ratio of +15 per mil. The probable source is from the resolution of evaporites which were enriched in $\delta \mathrm{O}^{18}$ as a result of sulfate-water isotopic equilibration. A fresh flooding of the Mediterranean basins caused the resolution of evaporites, an isotopic homogenization of the sulfate ions and subsequent transport within or to the Antalya Basin for reprecipitation at Sites 376. This secondary source was continuous until the end of large-scale gypsum deposition in Core 17.

Two recorded changes are of notable interest. Sample 18-1, 141-142 cm has an increasing ratio for $\delta \mathrm{S}^{34}$ indicative of a temporary renewal of bacterial activity. Perhaps, this represents a heavy flooding interval in the basin, a freshening of the stagnant brine conditions. With Sample 17-1, 80-81 cm, there appears to be a slight trend towards decreased $\delta \mathrm{O}^{18}$, a return towards normal sulfate isotopic values as seen in Hole $378 \mathrm{~A}$.

\section{Site 378A - Aegean Basin}

The constancy in the stable isotopic data of the Messinian evaporites from the Aegean Basin indicates that it must have resembled a modern evaporite basin. The $\delta \mathrm{O}^{18}$ and $\delta \mathrm{S}^{34}$ values are very close to values obtained for upper Miocene evaporites in Tuscany (Cortecci, 1973). The Tuscany formations were probably formed in relatively small, shallow basins under climatic conditions close to those observed today. If the total amount of inflowing water is essentially balanced by an equal amount of evaporation, a steady-state situation is approached. The volume of water inside the evaporating basin remains constant between $10 \%$ to $30 \%$ of the oriqinal volume. Gypsum preciptiation occurs over a large area of the basin. Under these conditions, the concentration of the brine is kept within a narrow range and a positive correlation exists between salinity and distance from the sill. The oxygen and sulfur isotopic compositions remain fairly constant throughout deposition and are equal to the isotopic composition of the inflowing water. Unlike the Ionian Basin and Antalya Basin, the Aegean Basin was a "normal" evaporite basin during the Messinian. The isotopic content of the Aegean evaporites reflects the value of the dissolved sulfate input into the basins. These average ratios, $\delta \mathrm{O}^{18}=+15$ per mil and $\delta S^{34}=+22$ per mil, were found in the basal evaporites at Sites 374 and 376.

\section{CONCLUSIONS}

The isotopic results from our study of evaporites recovered at DSDP Sites 374, 376, and Hole 378A indicate the existence of three distinctly different basins in the eastern Mediterranean during the Messinian 
Salinity Crisis. In the Aegean Basin, normal steadystate conditions prevailed and the isotopic composition of the precipitated sulfate remained stable. The situation in the Ionian Basin was drastically different. Extremely stagnant evaporitive conditions (high salt concentration) diminished the bacterial activity allowing the oxygen-18 content of the sulfates to evolve towards an enriched equilibrium value. A similar isotopic evolution was cut short at Site 376 by the desiccation at the higher regions of the Antalya Basin. Site 376 was subsequently reflooded by a water containing sulfate ions highly enriched in oxygen-18.

\section{ACKNOWLEDGMENTS}

We would like to thank K. J. Hsü, A. Longinelli, and G. Cortecci for stimulating discussions during the course of this work, which was carried out at the Laboratorio di Geologia Nucleare, Pisa, Italy, and was supported by C.N.R.-University of Pisa Grant 74.00723 and Swiss National Science Foundation Grant 2.765-0.72

K. J. Hsü critically read a final draft of the manuscript.

\section{REFERENCES}

Cortecci, G., 1973. Analisi isotopica di una formazione evaporitica del Miocene Superiore: Rend. Soc. Ital. Miner. Petrol., v. 29, p. 3-18.

Cortecci, G., Ginesi, C., and Longinelli, A., 1975. Composizione isotopica dello zolfo. Tecniche di preparazione e di misura e primi risultati: Rend. Soc. Ital. Miner. Petrol., v. 31, p. $399-408$.

Craig, H., 1961. Standard for reporting concentrations of deuterium and oxygen-18 in natural waters: Science, v. 133 , p. $1833-1834$

Lloyd, R. M., 1967. Oxygen-18 composition of the oceanic sulfate: Science, v. 156, p. 1228-1231.

1968. Oxygen isotope behavior in the sulfate water system: J. Geophys. Res., v. 73, p. 6099-6110.

Longinelli, A., 1968. Oxygen isotopic composition of sulfate ions in water from thermal springs: Earth Planet. Sci. Lett., v. 4, p. 206-214.

Longinelli, A. and Craig, H., 1967. Oxygen-18 variations in sulfate ions in sea water and saline lakes: Science, v. 156, p. 56-59.

Mizutani, Y. and Rafter, T. A., 1969. Oxygen isotopic composition of sulfates, Part 4: Bacterial fractionation of oxygen isotopes in the reduction of sulfate and in the oxidation of sulphur: New Zealand J. Sci., v. 12, p. 60-68.

Rafter, T. A., 1957. Sulphur isotopic variations in nature, Part 1: The preparation of sulphur dioxide for mass spectrometer examination: New Zealand J. Sci. Tech., v. 38 , p. $849-857$.

Ryan, W. B. F., Hsü, K. J., et al., 1973. Initial Report of the Deep Sea Drilling Project, Volume 13: Washington (U.S. Government Printing Office).

Wallhauser, K. H. and Puchelt, U., 1965. Sulfate reducing bacteria in sulphur springs and underground waters of Germany and Austria: Contrib. Miner. Petrol., v. 13, p. 12-30. 